\title{
Rapid Action of Aldosterone on Protein Expressions of Protein Kinase C Alpha and Alpha1 Sodium Potassium Adenosine Triphosphatase in Rat Kidney
}

Somchit Eiam-Ong ${ }^{1 *},{\text { Kittisak Sinphitukkul' }{ }^{1}, \text { Krissanapong Manotham }^{2} \text { and Somchai Eiam-Ong }}^{3}$

${ }^{1}$ Department of Physiology, Faculty of Medicine, Chulalongkorn University, Bangkok, Thailand

${ }^{2}$ Department of Medicine, Lerdsin General Hospital, Bangkok, Thailand

${ }^{3}$ Deparment of Medicine (Division of Nephrology), Faculty of Medicine, Chulalongkorn University, Bangkok, Thailand

\begin{abstract}
Previous in vitro studies showed that aldosterone rapidly stimulates protein kinase $C$ alpha (PKC $\alpha$ ) that could activate alpha $(\alpha) 1$ isoform of $\mathrm{Na}$, K-ATPase and then enhances its activity. There are, however, no in vivo data that demonstrate the rapid effects of aldosterone on renal protein expressions of PKC $\alpha$ and $\alpha 1-\mathrm{Na}, \mathrm{K}-\mathrm{ATPase}$ simultaneously. The present study further investigates the expression of these proteins. Male Wistar rats were intraperitoneally injected with normal saline solution or aldosterone (150 $\mu \mathrm{g} / \mathrm{kg} \mathrm{BW})$. After 30 minutes, abundances and localizations of PKC $\alpha$ and $\alpha 1$ $\mathrm{Na}, \mathrm{K}-\mathrm{ATP}$ ase proteins were determined by Western blot analysis and immunohistochemistry, respectively. Aldosterone administration significantly increased plasma aldosterone levels from 1,251.95 \pm 13.83 to $6,521.78 \pm 209.92 \mathrm{pmol} / \mathrm{L}$. By Western blot analysis, aldosterone enhanced renal protein abundances of PKC $\alpha$ (homogenate samples) and $\alpha 1$ $\mathrm{Na}$, K-ATPase (plasma membrane) approximately $50 \%$ and $30 \%$, respectively $(P<0.05)$. From immunohistochemistry examination in sham group, the protein expression of PKC a was prominent in the medulla. Aldosterone stimulated the expression both in the cortex and medulla with the translocation from the basolateral to luminal side of the proximal convoluted tubule (PCT). As for a1-Na, K-ATPase protein expression, the sham rats showed a strong immunostaining in the distal convoluted tubules, collecting ducts, and thick ascending limbs. Aldosterone elevated the expression in the PCT and medullary collecting duct (MCD). This in vivo study is the first to demonstrate simultaneously that aldosterone rapidly elevates PKC $\alpha$ and $\alpha 1-\mathrm{Na}$, K-ATPase protein abundances in rat kidney. Both immunoreactivities were stimulated in the cortex and medulla. The greater affected areas were noted for PKC $\alpha$ expression, whereas the alterations of a1-Na, K-ATPase were observed only in the PT and MCD. The stimulation of $\mathrm{Na}$, K-ATPase protein expression by aldosterone, per se, may occur through PKC activation.
\end{abstract}

Keywords: Rapid action; Aldosterone; PKC $\alpha$; $\alpha 1-\mathrm{Na}$, K-ATPase; Protein abundance; Immunohistochemistry; Rat kidney

\section{Introduction}

The rapid nongenomic effect of aldosterone regulates wide varieties of cellular responses including the regulation of ion transport [1]. One of the key signaling mediators regulating this action is protein kinase C (PKC) [1]. The activation of PKC is a prominent aspect of the aldosterone-stimulated rapid signaling responses in epithelia [2]. In the kidney, PKC modulates several physiological functions of renal epithelial cells, including the transport of sodium, water, and organic anions and cations [3].

It has been shown that aldosterone administration of cortical collecting duct (CCD) cells results in the rapid activation of protein kinase C alpha (PKC a) [4]. PKC also stimulates the alpha (a) 1 isoform of $\mathrm{Na}, \mathrm{K}$-ATPase property [5]. Rapid responses of aldosteroneinduced $\mathrm{Na}, \mathrm{K}$-ATPase function in renal cells have been reported [6-8]. In vitro studies showed that aldosterone rapidly induces $\mathrm{Na}$, K-ATPase activity in rat microdissected CCD and in Madin-Darby canine kidney (MDCK) cells $[9,10]$. In animal investigation, after 30 minutes of intravenous injection of aldosterone in adrenalectomized rats, Na, K-ATPase activity was increased markedly in microdissected medullary thick ascending limb (mTAL) of Henle's loop and CCD but not in MCD [11].

At present, there are no available in vivo data regarding the rapid effects of aldosterone on protein abundance and localization of renal PKC $\alpha$ and $\alpha_{1}-\mathrm{Na}$, K-ATPase, simultaneously performed in the same study. Therefore, this study examined rat kidneys 30 minutes after normal saline solution or aldosterone injection with use of Western blot analysis and immunohistochemistry to determine protein abundance and localization of renal PKC $\alpha$ and $\alpha_{1}-\mathrm{Na}$, K-ATPase.

\section{Materials and Methods}

\section{Experimental design}

Male Wistar rats weighing 200-240 g (National Center of Scientific Use of Animals, Mahidol University, Nakornpathom, Thailand) were given conventional housing and diet. All animal protocols were approved by the Ethics Committee of Research, Chulalongkorn University. Serum creatinine of each rat should be $<1 \mathrm{mg} / \mathrm{dl}[12,13]$. The rats were divided into two groups ( $n=8 /$ group): sham (normal saline solution; NSS: $0.5 \mathrm{ml} / \mathrm{kg}$ BW by intraperitoneal injection, i.p.); and Aldo (aldosterone $150 \mu \mathrm{g} / \mathrm{kg}$ BW, diluted in NSS, i.p.; Sigma, St. Louis, MO, USA). We used this dose as previously performed in the study of rapid action of aldosterone on the protein expressions of

*Corresponding author: Somchit Eiam-Ong, Associate Professor, Department of Physiology, Faculty of Medicine, Chulalongkorn University, Bangkok, Thailand 10330, Tel: (662) 256-4267; Fax: (662) 256-4267; E-mail: eiamong@yahoo.com

Received January 21, 2014; Accepted February 20, 2014; Published March 05, 2014

Citation: Eiam-Ong S, Sinphitukkul K, Manotham K, Eiam-Ong S (2014) Rapid Action of Aldosterone on Protein Expressions of Protein Kinase C Alpha and Alpha1 Sodium Potassium Adenosine Triphosphatase in Rat Kidney. J Steroids Horm Sci 5: 125. doi:10.4172/2157-7536.1000125

Copyright: (c) 2014 Eiam-Ong S, et al. This is an open-access article distributed under the terms of the Creative Commons Attribution License, which permits unrestricted use, distribution, and reproduction in any medium, provided the original author and source are credited. 
Citation: Eiam-Ong S, Sinphitukkul K, Manotham K, Eiam-Ong S (2014) Rapid Action of Aldosterone on Protein Expressions of Protein Kinase C Alpha and Alpha1 Sodium Potassium Adenosine Triphosphatase in Rat Kidney. J Steroids Horm Sci 5: 125. doi:10.4172/2157-7536.1000125

Page 2 of 5

upstream mediators [12]. Therefore, in the present investigation, we further examine this dose on PKC $\alpha$ and $\alpha_{1}-\mathrm{Na}, \mathrm{K}-\mathrm{ATPase}$.

On the date of the experiment, after a 30 -minute injection period of NSS or aldosterone, the rats were anesthetized with thiopental (100 $\mathrm{mg} / \mathrm{kg}$ BW, i.p.). Kidneys were removed, and a half of each kidney was fixed in liquid nitrogen, and then stored at $-80^{\circ} \mathrm{C}$ until use for measurement of PKC $\alpha$ and $\alpha 1-\mathrm{Na}$, K-ATPase protein abundances by Western blot analysis. The other half of renal tissue was fixed in $10 \%$ paraformaldehyde for localization of these proteins by immunohistochemistry [12].

\section{Western blot analysis}

The renal tissue samples were homogenized on ice with a homogenizer (IKA, T25 Basic, Selangor, Malaysia) in homogenizing buffer [( $20 \mathrm{mM}$ Tris- $\mathrm{HCl}$; $\mathrm{pH} 7.5,2 \mathrm{mM} \mathrm{MgCl}, 0.2 \mathrm{M}$ sucrose, and $5 \%(\mathrm{v} / \mathrm{v})$ protease inhibitor cocktail (Sigma, MO, USA)]. To get rid of crude debris, the kidney homogenates were centrifuged at 12,000 g (Biofuge PrimoR, Heracus, Germany) for 20 minutes at $4^{\circ} \mathrm{C}$. The supernatant was collected and used as homogenate sample. To harvest plasma membrane, this supernatant was centrifuged at $37,500 \mathrm{~g}$ for 20 minutes at $4^{\circ} \mathrm{C}$ [14]. The pellet was dissolved in buffer. Total protein concentration of both homogenate samples and plasma membrane were measured with Bradford protein assay reagent (Pierce, Rockford, IL, USA) following the manufacturer's protocol. The measurement of protein abundance was performed as previously described [12]. Proteins were resolved on $8 \%$ sodium dodecyl sulfate polyacrylamide gel eletrophoresis (SDS-PAGE) for PKC $\alpha, \alpha 1-\mathrm{Na}, \mathrm{K}-\mathrm{ATPase}$, or $\beta$-actin, and blotted onto nitrocellulose membrane (Bio-Rad, Hercules, CA, USA). The membranes were incubated with primary monoclonal antibody to PKC a (H-7: sc-8393; 1:1000; Santa Cruz Biotechnology, Santa Cruz, CA, USA), a1-Na, K-ATPase (C464.6; 1:2500; Millipore, Temecula, CA, USA), or to $\beta$-actin (Santa Cruz Biotechnology), followed by the respective horseradish peroxidase-linked secondary antibody (Bio-Rad). Immunoreactive proteins were detected by chemiluminescence detection (Super Signal West Pico kit; Pierce) and exposed to film (CL-XPosure ${ }^{\mathrm{TM}}$; Pierce). Relative protein levels of PKC $\alpha$ and $\alpha 1-\mathrm{Na}, \mathrm{K}-\mathrm{ATP}$ ase in each sample were presented as a percentage of the control normalized to its $\beta$-actin content.

\section{Immunohistochemical study}

Detection of protein localization was performed as previously described [12]. Paraffin-embedded kidney sections were cut at $4 \mu \mathrm{m}$ in thickness. The slides were deparaffinized and endogenous peroxidase was blocked by treatment with $3 \% \mathrm{H}_{2} \mathrm{O}_{2}$. The sections were incubated with the primary antibody PKC a (1:400; Santa Cruz Biotechnology), or a1-Na, K-ATPase (1:2000; Millipore) at $4^{\circ} \mathrm{C}$ overnight, followed by the respective horseradish peroxidase-linked secondary antibody (BioRad), then reacted with 3,3'-diaminobenzidine (DAB) solution (Sigma). Three pathologists independently scored the staining intensity on a semi-quantitative five-tiered grading scale from 0 to $4(0=$ negative; 1 =trace; $2=$ weak; 3 =moderate; $4=$ strong) as previously described [12].

\section{Statistical analysis}

Results of renal PKC $\alpha$ and $\alpha 1-\mathrm{Na}, \mathrm{K}-\mathrm{ATPase}$ protein abundances were expressed as mean \pm SD. Statistical differences between the groups were assessed by ANOVA (analysis of variance) with post-hoc comparison by Tukey's test where appropriate. A P value of $<0.05$ was considered statistically significant. Statistical tests were analyzed using SPSS program version 15.0 (SPSS Inc., Chicago, IL, USA). Median staining intensity (score) of renal PKC $\alpha$ and $\alpha 1-\mathrm{Na}, \mathrm{K}-\mathrm{ATP}$ ase protein expressions was presented as previously described [12].

\section{Results}

\section{Effect of aldosterone on renal PKC $\alpha$ and $\alpha 1-\mathrm{Na}, \mathrm{K}-\mathrm{ATPase}$ protein abundances}

The protein levels of PKC a $(80 \mathrm{kDa})$ and $\alpha 1-\mathrm{Na}, \mathrm{K}-\mathrm{ATPase}(130$ $\mathrm{kDa}$ ) were assessed in the rat kidney with Western blot analysis. As shown in Figure 1, aldosterone significantly enhanced protein abundance of renal PKC $\alpha$ in homogenate samples (sham $=100 \%$; Aldo $=152.5 \pm 9.8 \%, P<0.05)$. Interestingly, aldosterone elevated protein abundance of $\alpha 1-\mathrm{Na}, \mathrm{K}-\mathrm{ATPase}$ only in the plasma membrane (sham= $100 \%$; Aldo $=131.9 \pm 8.9 \%, P<0.05)$.

\section{Effect of aldosterone on renal PKC a protein localization}

The rapid action of aldosterone on PKC $\alpha$ expression in the rat kidney was examined by immunohistochemistry. As shown in Table 1, in the cortex of sham, immunoreactivity of renal PKC a protein distribution/ localization was moderate in the glomerulus, whereas trace staining was observed in the peritubular capillary (Pcap), basolateral side of proximal convoluted tubule (PCT) and of distal convoluted tubule (DCT; Figure 2a). In the cortical collecting duct (CCD), the expression was weak. Aldosterone increased the immunoreactivity from trace to be weak in PCT with the translocation from the basolateral to luminal side (Figure $2 \mathrm{~b}$ ). The intensity score in the glomeruli was elevated from 3 to 4, and in Pcap from 1 to 2 by aldosterone (Figure 2b). Of noted, no staining in the DCT and CCD was detected after aldosterone administration.

In the outer stripe of outer medulla $(\mathrm{OM})$ of the Aldo group, immunoreactivity in the thick ascending limb of Henle's loop (TALH), medullary collecting duct (MCD), and proximal straight tubule (PTs) was enhanced (Figures $2 \mathrm{c}$ and $2 \mathrm{~d}$ ). In the inner stripe of $\mathrm{OM}$ (Figures 2e and 2f), aldosterone increased staining in both apical and basolateral sides of TALH (score $=2$ ) and MCD (score=3), whereas the strong expression was noted in the vasa recta (VR) and thin limb of

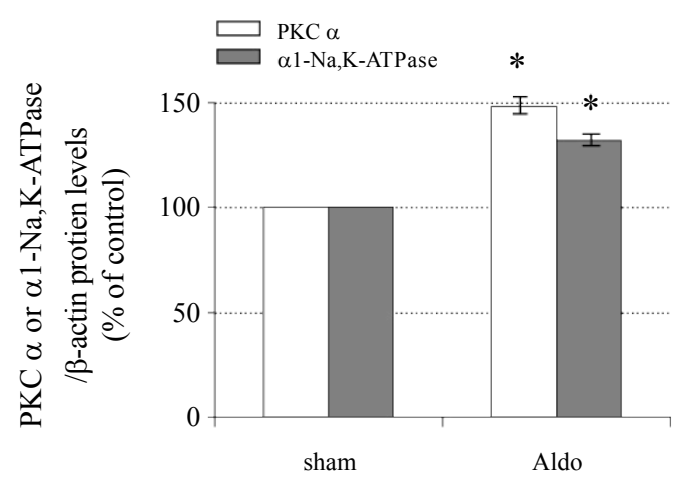

$\operatorname{PKC} \alpha$

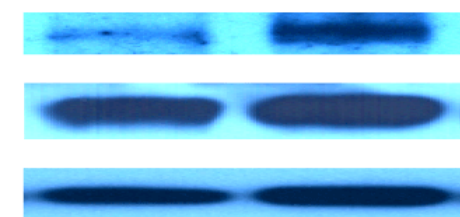

$\operatorname{Mr}(\mathrm{kDa})$

80

$\beta$-Actin

Figure 1: Western blot analysis of renal PKC $\alpha$ and $\alpha 1-\mathrm{Na}, \mathrm{K}-\mathrm{ATP}$ ase protein abundances in sham and Aldo groups. Histogram bars show the densitometric analyses ratios of PKC $\alpha$ or $\alpha 1-\mathrm{Na}, \mathrm{K}-\mathrm{ATP}$ ase to $\beta$-actin intensity, and the representative immunoblot photographs are presented. Data are means \pm SD of 8 independent experiments. ${ }^{*} P<05$ compared with the sham group. 
Citation: Eiam-Ong S, Sinphitukkul K, Manotham K, Eiam-Ong S (2014) Rapid Action of Aldosterone on Protein Expressions of Protein Kinase C Alpha and Alpha1 Sodium Potassium Adenosine Triphosphatase in Rat Kidney. J Steroids Horm Sci 5: 125. doi:10.4172/2157-7536.1000125

Page 3 of 5

\begin{tabular}{|c|c|c|c|c|}
\hline & \multicolumn{4}{|c|}{ Median staining intensity (score) } \\
\hline & \multicolumn{2}{|c|}{ PKC a } & \multicolumn{2}{|c|}{ a1-Na,K-ATPase } \\
\hline & sham & Aldo & sham & Aldo \\
\hline \multicolumn{5}{|l|}{ Cortex } \\
\hline Glomerulus & 3 & 4 & 0 & 0 \\
\hline PCT & 1 & 3 & 2 & 3 \\
\hline DCT & 1 & 0 & 4 & 4 \\
\hline CCD & 2 & 0 & 4 & 4 \\
\hline Pcap & 1 & 2 & 1 & 1 \\
\hline \multicolumn{5}{|l|}{ Outer medulla } \\
\hline \multicolumn{5}{|l|}{ Outer stripe } \\
\hline TALH & 3 & 4 & 4 & 4 \\
\hline MCD & 3 & 4 & 4 & 4 \\
\hline PTs & 1 & 2 & 3 & 2 \\
\hline \multicolumn{5}{|l|}{ Inner stripe } \\
\hline TALH & 1 & 2 & 4 & 4 \\
\hline MCD & 1 & 3 & 2 & 3 \\
\hline VR & 3 & 4 & 1 & 1 \\
\hline $\mathrm{tLH}$ & 3 & 4 & 1 & 1 \\
\hline \multicolumn{5}{|l|}{ Inner medulla } \\
\hline MCD & 4 & 2 & 3 & 4 \\
\hline VR & 4 & 4 & 1 & 1 \\
\hline tLH & 3 & 4 & 1 & 1 \\
\hline
\end{tabular}

Staining intensity: 0 : negative, no reactivity; 1 : trace, faint, or pale brown staining with less membrane reactivity; 2 : weak, light brown staining with incomplete membrane reactivity; 3 : moderate, shaded of brown staining of intermediate darkness with usually almost complete membrane reactivity; 4 : strong, dark brown to black staining with usually complete membrane pattern, producing a thick outline of the cell [10].

PCT: Proximal Convoluted Tubule; DCT: Distal Convoluted Tubule; CCD: Cortical Collecting Duct; Pcap: Peritubular capillary; TALH: Thick Ascending Limb of Henle's Loop; MCD: Medullary Collecting Duct; PTs: Proximal Straight Tubule; VR=Vasa Recta; tLH: thin limb of Henle's loop.

Table 1: Median staining intensity (score) of renal PKC $\alpha$ and $\alpha_{1}-\mathrm{Na}, \mathrm{K}-\mathrm{ATPase}$ protein expressions.

Henle's loop (tLH). In the inner medulla (IM), immunoreactivity in VR remained strong, whereas the expression was elevated in tLH but declined in MCD by aldosterone (Figures $2 \mathrm{~g}$ and $2 \mathrm{~h}$ ) (Table 1 ).

\section{Effect of aldosterone on renal al-Na, K-ATPase protein localization}

The immunostaining of al-Na, K-ATPase protein expression was obvious at the basolateral membrane both in the cortex and medulla. In sham (Figure $3 \mathrm{a}$ and Table 1), the expression was strong in the DCT and CCD, whereas the staining was weak in the PCT and trace in Pcap. No staining was noted in the glomerulus. Aldosterone increased the intensity score only in the PCT to 3 (Figure $3 \mathrm{~b}$ ).

In the outer stripe of $\mathrm{OM}$, aldosterone slightly suppressed the intensity score in the PTs from 3 to 2 (Figures $3 \mathrm{c}$ and $3 \mathrm{~d}$ ), whereas the strong immunoreactivity in the TALH and MCD remained. In the inner stripe of $\mathrm{OM}$, aldosterone elevated the intensity score from 2 to 3 in the MCD, whereas the staining in the TALH, VR and tLH did not change (Table 1, Figures $3 e$ and $3 f$ ). In the IM, immunoreactivity was enhanced to be strong in the MCD, while the intensity score in the VR and tLH did not alter (Figures $3 \mathrm{~g}$ and $3 \mathrm{~h}$ )

\section{Discussion}

The results in the present study are the first in vivo data that simultaneously show both renal PKC $\alpha$ and $\alpha 1-\mathrm{Na}, \mathrm{K}-\mathrm{ATPase}$ protein expressions after 30-min aldosterone administration. According to Western blot analysis, aldosterone significantly enhanced renal PKC a

protein level from homogenate samples by approximately 50\% (Figure 1). A previous in vitro study in rat cortical collecting duct cells showed that aldosterone administration for 15 min could enhance activity as well as protein abundance of PKC a with time- and dose-dependent manners [4]. Moreover, aldosterone promotes the activation of PKC $\alpha$ in MR-independent pathway [15]. The mechanism that aldosterone could activate PKC $\alpha$ has been clarified. One outstanding in vitro examination demonstrated the direct interaction between aldosterone with PKC a that has the specific binding site within the $\mathrm{C}_{2}$ domain, resulting in activation and auto phosphorylation of the kinase [16]. Therefore, PKC a serves as a receptor for aldosterone inducing the rapid effects $[16,17]$. Our present data provide the evidence that aldosterone rapidly activates $\mathrm{PKC}$ a protein expression in vivo.

For protein localization in the sham group, the immunoreactivity of PKC a was expressed in both cortex and medulla (Table 1 and Figure 2). In the cortex, the expression was abundant in the glomerulus with a lesser extent in PCT, DCT, and CCD. The more intense immunoreactivity of PKC $a$ was observed in the TALH and MCD (outer stripe), VR and tLH (inner stripe) of the outer medulla. The reactivity was strong in the inner medulla. The baseline regional distribution of PKC a protein in the present study is in agreement with a previous study in normal rat kidney [18]. The present study shows that aldosterone had a greater activation on PKC $\alpha$ in the medulla area, especially at both membrane sides of TALH and MCD (Table 1 and Figures $2 \mathrm{c}-\mathrm{f}$ ). Furthermore, aldosterone stimulated the translocation of PKC a expression from basolateral to apical membrane of PCT

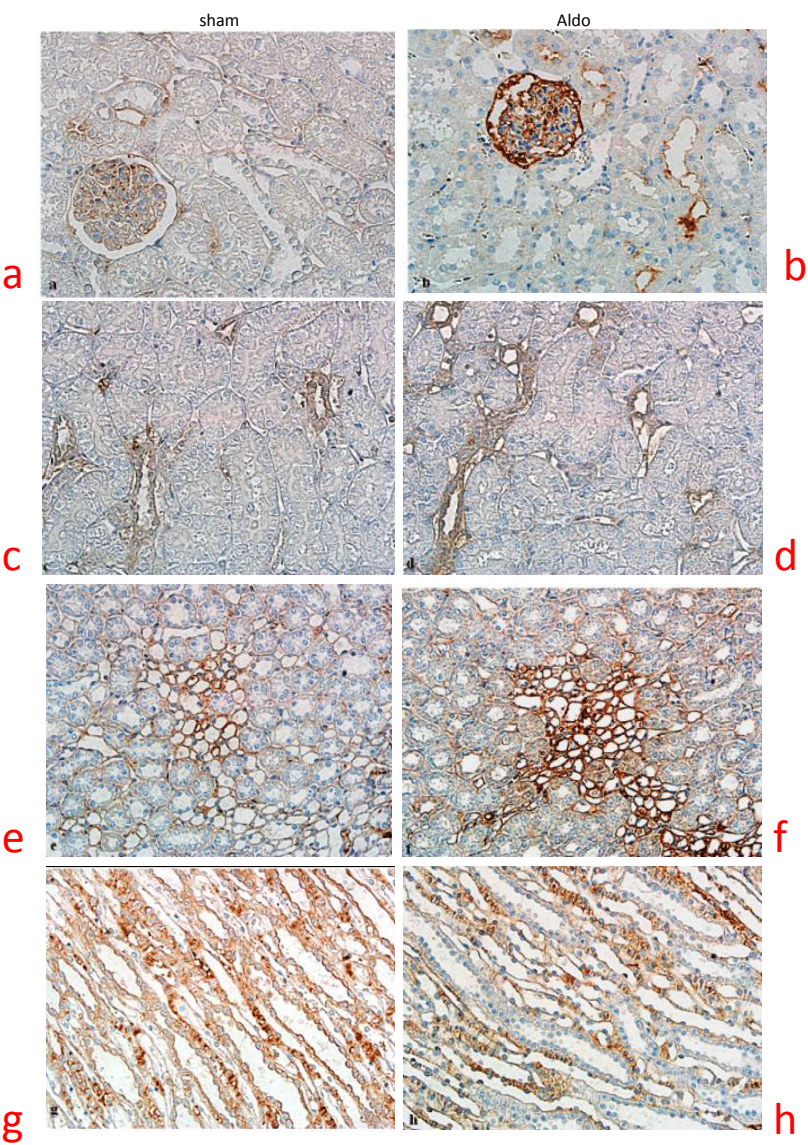

Figure 2: PKC a protein expression. 
(Figure 2b). This suggests a significant action of aldosterone on tubular transport via PKC in this segment.

The PKC signaling cascades that are rapidly activated in response to aldosterone are emerging as important modulators of the functional changes in several cell types [2]. In vitro investigations related to the kidney have demonstrated that PKC could regulate renal cell function. PKC activation by phorbol myristate acetate for 4 minutes increased sodium hydrogen exchanger 3 activity in luminal membrane vesicle isolated from rat kidney cortical tubules [19]. Previous studies demonstrated that PKC plays an important role to maintain normal cellular functions and to mediate repair of mitochondrial and transport functions after toxicant-induced injury [20] as well as regulation of cell survival in renal proximal tubular cells [3]. Further in vivo study is required to clarify this circumstance. However, a recent study in mice kidney revealed that PKC a protects against angiotensin II-induced decreases in urine concentrating ability by maintaining aquaporin 2 water channels [21].

As for Na, K-ATPase, this ubiquitous membrane-bound enzyme composes of at least two subunits: the a subunit carrying the catalytic and ion transport properties and the $\beta$ subunit involving in enzyme maturation and modulation of transport activity [22]. The fundamental function of $\mathrm{Na}, \mathrm{K}-\mathrm{ATP}$ ase is to regulate and maintain high sodium and potassium gradient across the plasma membrane of animal cells [22]. In renal tubular epithelial cells, $\mathrm{Na}, \mathrm{K}$-ATPase provides the driving force for active sodium reabsorption and its activity is modulated by multihormonal control, including aldosterone $[8,23]$. For protein localization in the sham group, the immunoreactivity of al-Na, K-ATPase was expressed abundantly in both cortex and medulla (Table 1 and Figure 3). In the cortex, the tubular areas had prominent staining in DCT and CCD, whereas the reactivity in TALH and MCD was obvious in the medulla. The baseline regional distribution of this protein in the present study is in agreement with a previous study in normal rat kidney [24]. The present results show that aldosterone enhanced immunoreactivity in the PCT to be moderate, and in the inner MCD to be strong (Table 1 and Figures $3 a, 3 b, 3 e-3 h$ ).

Since the collecting duct is the major site of aldosterone action for regulating $\mathrm{Na}$, K-ATPase, many investigations in rapid action of aldosterone have provided the data from this segment. Previous in vitro examinations demonstrated that aldosterone produces a rapid stimulation of $\mathrm{Na}$, K-ATPase activity in microdissected CCD and MDCK epithelial cells $[9,10]$. An intravenous infusion of aldosterone, for 30 minutes into the rat, also stimulated the $\mathrm{Na}, \mathrm{K}$-ATPase activity in microdissected CCD but reduced sodium excretion [11]. The authors revealed that aldosterone produces this rapid stimulation of pump activity via increased transporting rate assessed by ouabain-sensitive ${ }^{86} \mathrm{Rb}$ uptake assay [9]. Therefore, further investigation is needed to delineate whether aldosterone could affect this $\mathrm{Na}, \mathrm{K}$-ATPase property in the PCT.

For protein abundance, a previous examination showed that aldosterone administration for 15 minutes in renal collecting duct cells did not alter a1-Na, K-ATPase protein abundance [4]. However, in the present study, aldosterone injection for 30 minutes could enhance a1-Na, K-ATPase protein abundance from plasma membrane by $30 \%$, whereas no changes were observed from homogenate samples (data not shown). Since this time course ( 30 minutes) is not enough for processes of transcription or translation the protein. Some investigations have provided explanations regarding to this alteration. In MDCK cells, the ${ }^{3} \mathrm{H}$-ouabain binding assay indicated that aldosterone increased in pump numbers due to insertion of preexisting units [10]. Moreover, a previous

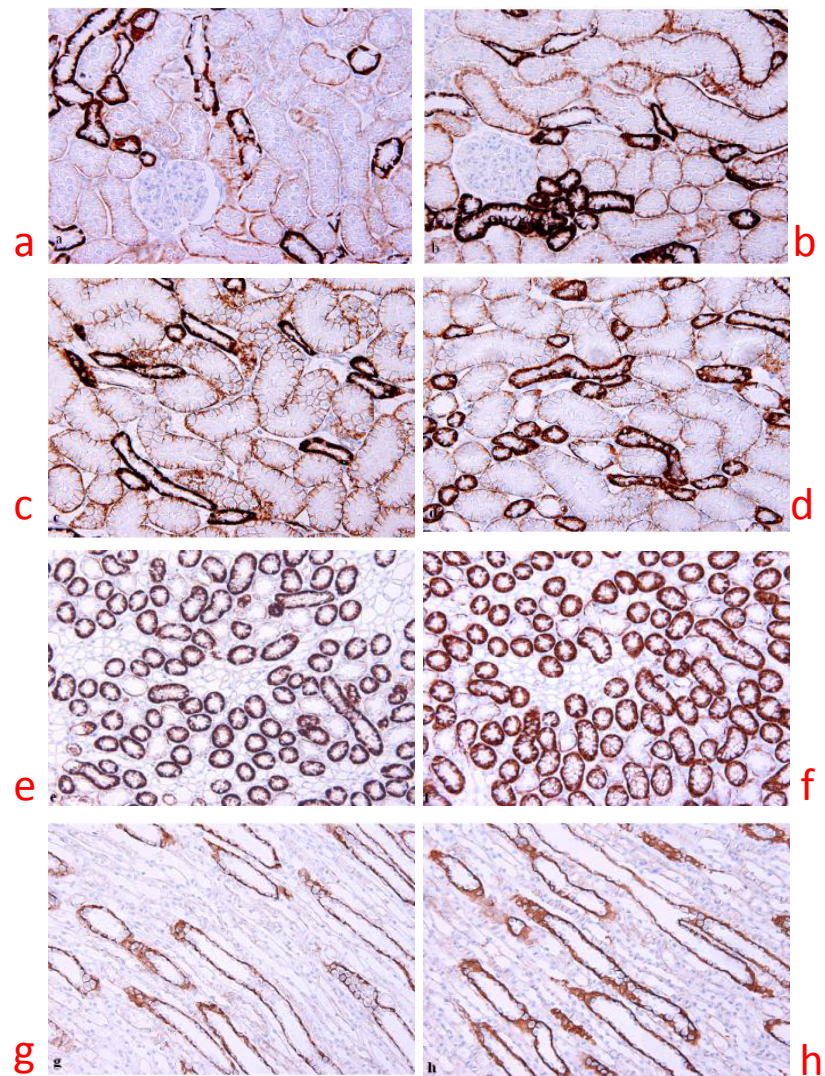

Figure 3: a1-Na, K-ATPase protein expression.

in vitro study demonstrated that, in the presence of aldosterone, a rise in cell sodium induces the recruitment and activation of latent pump at the basolateral membrane of rabbit CCD cells within 2-3 seconds [25]. Therefore, we suggest that the elevation of a1-Na, K-ATPase protein abundance in the present study may occur by the recruitment of the pump protein preexisting in the tubular cell which inserted to the plasma membrane.

Our present study demonstrates that both PKC $\alpha$ and $\alpha 1$ $\mathrm{Na}, \mathrm{K}-\mathrm{ATP}$ ase were activated simultaneously by aldosterone. The influences of PKC on $\mathrm{Na}, \mathrm{K}$-ATPase property have been extensively examined. Several studies indicated that PKC activation could stimulate $\mathrm{Na}, \mathrm{K}$-ATPase. For example, a previous in vitro study in rat PCT provided clear evidences that direct activation of PKC by phorbol esters increases the affinity of $\mathrm{Na}, \mathrm{K}$-ATPase for sodium and thereby stimulates its transport activity [26]. Moreover, PKC activation induced phosphorylation of the catalytic a1-subunit of $\mathrm{Na}$, K-ATPase and stimulated the ouabain-sensitive ${ }^{86} \mathrm{Rb}$ uptake by $47 \%$ and $42 \%$, respectively in time- and dose-dependent fashions in the PCT [5]. Furthermore, in rat microdissected mTAL, the stimulation of $\mathrm{Na}, \mathrm{K}$-ATPase activity was associated with an increase in $\mathrm{Na}$, K-ATPase $\alpha$-subunit phophorylation through PKC- $\alpha$ activation [27]. In addition, it has been shown that aldosterone could rapidly stimulate another adenosine triphosphatase. A recent study demonstrated that aldosterone enhances vacuolar H-ATPase activity in renal acidsecretory intercalated cells mainly via a protein kinase C-dependent pathway [28]. Therefore, we propose that the increase in PKC activation in the present in vivo study may be accountable for $\mathrm{Na}$, K-ATPase stimulation. However, additional in vivo investigations are needed 
Citation: Eiam-Ong S, Sinphitukkul K, Manotham K, Eiam-Ong S (2014) Rapid Action of Aldosterone on Protein Expressions of Protein Kinase C Alpha and Alpha1 Sodium Potassium Adenosine Triphosphatase in Rat Kidney. J Steroids Horm Sci 5: 125. doi:10.4172/2157-7536.1000125

Page 5 of 5

to clarify whether this aldosterone action is MR-mediated process and dose-dependent manners. For further studies, we aim to unveil the rapid effects of aldosterone on the other sodium transporters and related PKC isoenzymes, such as $\beta$ subunits.

\section{Conclusion}

In conclusion, this is the first in vivo study which simultaneously demonstrates that aldosterone rapidly enhanced PKC $a$ and a1-Na, K-ATPase protein abundances in the rat kidney. Both immunoreactivities were stimulated in the cortex and medulla. The greater affected areas were noted for PKC a expression, whereas the alterations of a1-Na, K-ATPase were observed only in the PT and MCD. The stimulation of Na, K-ATPase protein expression by aldosterone, per se, may occur through PKC activation.

\section{Acknowledgements}

This study was supported by Grant no. RA 57/007 from the Ratchadapiseksompoth Research Fund, Faculty of Medicine, Chulalongkorn University.

\section{References}

1. Dooley R, Harvey BJ, Thomas W (2012) Non-genomic actions of aldosterone: from receptors and signals to membrane targets. Mol Cell Endocrinol 350: 223-234.

2. Thomas W, McEneaney V, Harvey BJ (2007) Aldosterone-stimulated PKC signalling cascades: from receptor to effector. Biochem Soc Trans 35: 10491051.

3. Dempsey EC, Newton AC, Mochly-Rosen D, Fields AP, Reyland ME, et al. (2000) Protein kinase $C$ isozymes and the regulation of diverse cell responses. Am J Physiol Lung Cell Mol Physiol 279: L429-438.

4. Le Moëllic C, Ouvrard-Pascaud A, Capurro C, Cluzeaud F, Fay M, et al. (2004) Early nongenomic events in aldosterone action in renal collecting duct cells: PKC $\alpha$ activation, mineralocorticoid receptor phosphorylation, and cross-talk with the genomic response. J Am Soc Nephrol 15: 1145-1160.

5. Carranza ML, Féraille E, Favre H (1996) Protein kinase C-dependent phosphorylation of $\mathrm{Na}(+)-\mathrm{K}(+)-A T P a s e$ alpha-subunit in rat kidney cortical tubules. Am J Physiol 271: C136-143.

6. Good DW (2007) Nongenomic actions of aldosterone on the renal tubule Hypertension 49: 728-739.

7. Harvey BJ, Alzamora R, Stubbs AK, Irnaten M, McEneaney V, et al. (2008) Rapid responses to aldosterone in the kidney and colon. J Steroid Biochem Mol Biol 108: 310-317.

8. Thomas W, Harvey BJ (2011) Mechanisms underlying rapid aldosterone effects in the kidney. Annu Rev Physiol 73: 335-357.

9. Fujii Y, Takemoto F, Katz Al (1990) Early effects of aldosterone on Na-K pump in rat cortical collecting tubules. Am J Physiol 259: F40-45.

10. Shahedi M, Laborde K, Bussières L, Sachs C (1993) Acute and early effects of aldosterone on Na-K-ATPase activity in Madin-Darby canine kidney epithelial cells. Am J Physiol 264: F1021-1026.

11. El Mernissi G, Doucet A (1983) Short-term effect of aldosterone on renal sodium transport and tubular Na-K-ATPase in the rat. Pflugers Arch 399: 139-146.

12. Eiam-Ong S, Sinphitukkul K, Manotham K, Eiam-Ong S (2013) Rapid nongenomic action of aldosterone on protein expressions of $\mathrm{Hsp} 90(\alpha \pm$ and $\beta$ ) and pc-Src in rat kidney. Biomed Res Int 2013: 346480

13. Sinphitukkul K, Eiam-Ong S, Manotham K, Eiam-Ong S (2011) Nongenomic effects of aldosterone on renal protein expressions of pEGFR and pERK1/2 in rat kidney. Am J Nephrol 33: 111-120.

14. Fernández-Llama $P$, Jimenez W, Bosch-Marcé M, Arroyo V, Nielsen S, et al.
(2000) Dysregulation of renal aquaporins and $\mathrm{Na}-\mathrm{Cl}$ cotransporter in $\mathrm{CCl} 4$ induced cirrhosis. Kidney Int 58: 216-228.

15. Markos F, Healy V, Harvey BJ (2005) Aldosterone rapidly activates $\mathrm{Na}+$ $\mathrm{H}+$ exchange in $\mathrm{M}-1$ cortical collecting duct cells via a PKC-MAPK pathway. Nephron Physiol 99: 1-9.

16. Alzamora R, Brown LR, Harvey BJ (2007) Direct binding and activation of protein kinase $\mathrm{C}$ isoforms by aldosterone and 17 beta-estradiol. Mol Endocrinol 21: $2637-2650$.

17. Alzamora R, Harvey BJ (2008) Direct binding and activation of protein kinase C isoforms by steroid hormones. Steroids 73: $885-888$.

18. Pfaff IL, Wagner HJ, Vallon V (1999) Immunolocalization of protein kinase C isoenzymes alpha, beta1 and betall in rat kidney. J Am Soc Nephrol 10: 18611873

19. Karim ZG, Chambrey R, Chalumeau C, Defontaine N, Warnock DG, et al. (1999) Regulation by PKC isoforms of $\mathrm{Na}(+) / \mathrm{H}(+)$ exchanger in luminal membrane vesicles isolated from cortical tubules. Am J Physiol 277: F773-778.

20. Nowak G (2003) Protein kinase C mediates repair of mitochondrial and transport functions after toxicant-induced injury in renal cells. J Pharmacol Exp Ther 306: 157-165.

21. Thai TL, Blount MA, Klein JD, Sands JM (2012) Lack of protein kinase C-c leads to impaired urine concentrating ability and decreased aquaporin-2 in angiotensin II-induced hypertension. Am J Physiol Renal Physiol 303: F37-44.

22. Pearce D, Bhalla V, Funder JW (2012) Aldosterone regulation of ion transport Brenner \& Rector's the kidney. (9th edn) W.B. Saunders Company, Philadelphia USA.

23. Féraille E, Doucet A (2001) Sodium-potassium-adenosinetriphosphatasedependent sodium transport in the kidney: hormonal control. Physiol Rev 81 : 345-418.

24. Wetzel RK, Sweadner KJ (2001) Immunocytochemical localization of Na-KATPase alpha- and gamma-subunits in rat kidney. Am J Physiol Renal Physiol 281: F531-F545.

25. Blot-Chabaud M, Wanstok F, Bonvalet JP, Farman N (1990) Cell sodiuminduced recruitment of $\mathrm{Na}(+)-\mathrm{K}(+)$-ATPase pumps in rabbit cortical collecting tubules is aldosterone-dependent. J Biol Chem 265: 11676-11681.

26. Féraille E, Carranza ML, Buffin-Meyer B, Rousselot M, Doucet A, et al. (1995) Protein kinase $\mathrm{C}$-dependent stimulation of $\mathrm{Na}(+)-\mathrm{K}(+)-\mathrm{ATP}$ epsilon in rat proximal convoluted tubules. Am J Physiol 268: C1277-1283.

27. Tsimaratos M, Roger F, Chabardès D, Mordasini D, Hasler U, et al. (2003) $\mathrm{C}$-peptide stimulates $\mathrm{Na}+, \mathrm{K}+-\mathrm{ATPase}$ activity via PKC alpha in rat medullary thick ascending limb. Diabetologia 46: 124-131.

28. Winter C, Kampik NB, Vedovelli L, Rothenberger F, Paunescu TG, et al. (2011) Aldosterone stimulates vacuolar $\mathrm{H}(+)$-ATPase activity in renal acid-secretory intercalated cells mainly via a protein kinase C-dependent pathway. Am Physiol Cell Physiol 301: C1251-1261. 